\title{
Impact of coronary intensive care unit in treatment of myocardial infarction
}

\author{
Marcia Cristina Todo ${ }^{1}$, Carolina Marabesi Bergamasco ${ }^{1}$, Paula Schmidt Azevedo ${ }^{2}$, Marcos Ferreira Minicucci ${ }^{3}$, \\ Roberto Minoru Tanni Inoue ${ }^{4}$, Marina Politi Okoshi ${ }^{3}$, Sergio Rupp de Paiva ${ }^{5}$, Leonardo Mamede ZornofF ${ }^{5}$, \\ Bertha Furlan Polegato ${ }^{2 *}$ \\ ${ }^{1}$ Medical Student, Faculdade de Medicina de Botucatu, Universidade Estadual Paulista (Unesp), Botucatu, SP, Brazil \\ ${ }^{2}$ Assistant PhD Professor, Department of Internal Medicine, Faculdade de Medicina de Botucatu, Unesp, Botucatu, SP, Brazil \\ ${ }^{3}$ Adjunct Professor, Department of Internal Medicine, Faculdade de Medicina de Botucatu, Unesp, Botucatu, SP, Brazil \\ ${ }^{4} \mathrm{MD}$, Department of Internal Medicine, Faculdade de Medicina de Botucatu, Unesp, Botucatu, SP, Brazil \\ ${ }^{5}$ Full Professor, Department of Internal Medicine, Faculdade de Medicina de Botucatu, Unesp, Botucatu, SP, Brazil
}



\section{SUMmARY}

Introduction: The mortality rate attributed to ST-segment elevation myocardial infarction (STEMI) has decreased in the world. However, this disease is still responsible for high costs for health systems. Several factors could decrease mortality in these patients, including implementation of cardiac intensive care units (CICU). The aim of this study was to evaluate the effect of CICU implementation on prescribed recommended treatments and mortality 30 days after STEMI.

Method: We performed a retrospective study with patients admitted to CICU between 2005 and 2006 (after group) and between 2000 and 2002, before CICU implementation (before group).

Results: The after group had 101 patients, while the before group had 143 patients. There were no differences in general characteristics between groups. We observed an increase in angiotensin-converting enzyme inhibitors, clopidogrel and statin prescriptions after CICU implementation. We did not find differences regarding number of patients submitted to reperfusion therapy; however, there was an increase in primary percutaneous angioplasty compared with thrombolytic therapy in the after group. There was no difference in 30-day mortality (before: 10.5\%; after: $8.9 \% ; \mathrm{p}=0.850$ ), but prescription of recommended treatments was high in both groups. Prescription of angiotensin-converting enzyme inhibitors and beta-blocker decreased mortality risk by 4.4 and 4.9 times, respectively. Conclusion: CICU implementation did not reduce mortality after 30 days in patients with STEMI; however, it increased the prescription of standard treatment for these patients.

Keywords: mortality, angiotensin-converting enzyme inhibitors, adrenergic antagonists.

\section{INTRODUCTION}

Ischemic heart disease (IHD) represents the main cause of mortality worldwide, accounting for $12.8 \%$ of deaths. ${ }^{1}$ Among the ischemic heart diseases, ST-segment elevation myocardial infarction (STEMI) is noteworthy, as not only it occurs more frequently with severe complications, such as cardiogenic shock and heart failure, ${ }^{2}$ but also the simple presence of the ST-segment elevation is an independent risk factor for mortality prediction. ${ }^{3-5}$
Although IHD mortality is declining in developed countries, ${ }^{5-7}$ the disease still represents a major health problem, as it causes high morbidity, worsening of quality of life and increased health expenditure. Data on IHD mortality in Brazil are still conflicting and vary according to the geographic region studied. ${ }^{1,8-11}$

Changes in mortality rates are due in part to the implementation of treatment protocols based on scientific evidence and to greater adherence to these protocols. ${ }^{5,6}$ 
A study performed in our service between 1992 and 1997, when there was no protocol established for the treatment of acute coronary syndromes, showed a 30-day mortality of $22.7 \% .^{12}$ After the implementation of the specific protocol, there was a $53 \%$ reduction in mortality. ${ }^{13}$

Other measures also contribute to a reduction in mortality from acute myocardial infarction, such as advances in reperfusion therapy, ${ }^{5,6,14}$ improved access of the population to health services ${ }^{1}$ and the creation of specific units for the treatment of acute coronary syndromes.

Coronary units arose in the 1960s and gained a lot of importance, especially after a study by Killip and Kimball, which showed a nearly $20 \%$ reduction in mortality with the creation of these units. ${ }^{15}$ Other subsequent studies have also shown positive results with the hospitalization of patients in coronary units. ${ }^{16-19}$

The coronary intensive care unit (CICU) was implemented at our service in 2004. However, assessments have not yet been made to determine if the creation of this unit specialized in the treatment of acute coronary syndromes was associated with a decrease in mortality or greater adherence to modern treatments recommended by the latest guidelines.

\section{Objective}

In view of the above, our objective was to evaluate the impact of implementing the CICU on the prescription of recommended treatments and 30-day mortality among patients with STEMI in a university tertiary hospital in the interior of the state of São Paulo.

\section{Method}

The study was approved by the local Research Ethics Committee (CAAE: 30209714.7.0000.5411; Opinion number: 637.778). A retrospective study was carried out based on the analysis of the medical records of patients hospitalized at the Coronary Unit of Hospital das Clínicas de Botucatu with a diagnosis of STEMI confirmed by electrocardiographic alteration (ST-segment elevation) and increase of myocardial injury markers (troponin, $\mathrm{CKMB}$ and $\mathrm{CPK}$ ). The period evaluated was from September 2005 to September 2006. This period was chosen because it was immediately after the implementation of the CICU, but included an interval wide enough to establish a pattern of care routines for patients with infarction.

Regarding the clinical profile of the patients, we analyzed sex, age, type of pain, duration of pain, heart rate and mean arterial pressure at admission. Risk factors of each patient were also evaluated: high blood pressure, diabetes mellitus, dyslipidemia, smoking, obesity and family history of heart disease in first-degree relatives.
As for characteristics of the infarction, the location of the pain, duration of pain until arrival at the service, presence and type of reperfusion therapy were investigated.

Data were collected on medications prescribed for patients hospitalized in the coronary unit, evaluating both symptomatic medications and those that alter the prognosis of the disease: acetylsalicylic acid (ASA), clopidogrel, glycoprotein IIb/IIIa inhibitors, beta-blockers, angiotensin converting enzyme (ACE) inhibitors, calcium channel blockers, statins, vasodilators, inotropes, diuretics and antiarrhythmics.

Lastly, the patients' hospitalization time and mortality 30 days after the infarction were evaluated. All the data collected from the patients were compared with the records of previous patients from the same service, also hospitalized with a diagnosis of STEMI but during the period from 2000 to 2002, prior to the CICU implantation. The group of patients evaluated from 2000 to 2002 was the "before group," while those patients admitted to the CICU in 2005 and 2006 comprised the "after group."

\section{Statistical analyses}

For the analysis of the categorical variables, $\chi^{2}$ test was used. For analysis of the normal distribution variables, t-test was used and the results were expressed as mean and standard deviation. Likewise, for the non-normal distribution variables, the Mann-Whitney test was used, with results expressed in medians and quartile 1 and 3 . Multivariate logistic regression was performed to identify factors that contributed to mortality. The level of significance was set at $5 \%$ for all analyses.

\section{RESULTS}

The number of patients analyzed from 2000 to 2002 was 143 , and from 2005 to 2006 it was 101 patients. We found no differences in age, sex, mean arterial pressure or mean heart rate at admission between the groups evaluated. The general characteristics of patients with STEMI are shown in Table 1.

Regarding the personal and family history of coronary disease, there was an $11 \%$ increase in the occurrence of family history compared to the period prior to the creation of the CICU, as shown in Table 1. Although there was no statistically significant difference, the high prevalence of hypertension and smoking in both groups stands out (Table 1).

There was no statistically significant difference between the groups in time elapsed from the onset of symptoms to hospital arrival ( $\mathrm{p}=0.765$ ), which was predominantly from 3 to 6 hours in both cases (before: $30.2 \%$; after: $27.9 \%)$. Twenty-eight percent of the patients in the 
TABLE 1 General characteristics of the population and prevalence of risk factors for ischemic heart disease among patients with acute myocardial infarction.

\begin{tabular}{llll} 
& $\begin{array}{l}\text { Before } \\
(\mathbf{n = 1 4 3 )}\end{array}$ & $\begin{array}{l}\text { After } \\
(\mathbf{n = 1 0 1})\end{array}$ & p-value \\
\hline MBP $(\mathrm{mmHg})$ & $98 \pm 22$ & $93 \pm 20$ & $0.058^{*}$ \\
\hline HR $(\mathrm{bpm})$ & $77(68-90)$ & $80(70-92)$ & $0.192^{\dagger}$ \\
\hline Age $($ years $)$ & $62(53-71)$ & $56(48-72)$ & $0.122^{\dagger}$ \\
\hline Male & $71 \%$ & $70 \%$ & $0.931^{\ddagger}$ \\
\hline High blood pressure & $66 \%$ & $61 \%$ & $0.535^{\ddagger}$ \\
\hline Diabetes mellitus & $32 \%$ & $28 \%$ & $0.580^{\ddagger}$ \\
\hline Dyslipidemia & $29 \%$ & $36 \%$ & $0.285^{\ddagger}$ \\
\hline Smoking & $66 \%$ & $71 \%$ & $0.468^{\ddagger}$ \\
\hline Positive family history & $14 \%$ & $25 \%$ & $0.045^{\ddagger}$
\end{tabular}

MBP: mean arterial blood pressure; HR: heart rate in beats per minute; $\mathrm{p}$-value: ${ }^{*} \mathrm{t}$ test; $†$ MannWhitney test; $\ddagger \chi^{2}$ test.

before group arrived at the service with less than three hours of pain while in the after group this happened with $30.8 \%$ of the patients. It is worth noting the large percentage of patients who arrived at the service with pain time greater than 12 hours, corresponding to $25 \%$ in the before group and $24.5 \%$ in the after group.

There was a predominance of STEMI located in the anterior wall in both groups (before: $43.4 \%$; after: $48,5 \%$ ), followed by STEMI of the inferior wall (before: $37.8 \%$; after: $35.5 \%$ ) and other locations (before: $18.8 \%$; after: $16 \%$ ), and we did not observe a statistically significant difference between the groups ( $\mathrm{p}=0.695$ ).

Regarding treatment, in the period before the creation of CICU, $60.1 \%$ of the patients received some type of reperfusion therapy, whereas in the period after the creation of CICU, the percentage of patients receiving reperfusion therapy was $70.7 \%(p=0.121)$. There was a decrease in the use of thrombolytic drugs as therapy of choice, which were used in $60 \%$ of the patients in the first interval and in $35 \%$ of the patients in the period after the implementation of CICU ( $p<0.001)$. This reduction in the use of thrombolytics was accompanied by an increase in the use of primary angioplasty as a treatment of choice, so that the latter was not performed in any patient from 2000 to 2002, but was used in $35 \%$ of patients between 2005 and 2006 ( $p<0.001$ ).

The results regarding drug treatment are shown in Figure 1. We observed a significant increase in the use of ACE inhibitors, clopidogrel, statins and glycoprotein IIb/IIIa inhibitors. Acetylsalicylic acid was used strongly in both periods, being prescribed to $97 \%$ of patients belonging to the group before and $100 \%$ of patients in the group after. The use of beta-blockers increased from
68 to $76 \%$, but without statistical significance. There was no difference in the use of symptomatic medications, either.

Finally, 30-day mortality after STEMI was $10.5 \%$ in the period prior to the implementation of the CICU and $8.9 \%$ after the CICU. Although we observed a reduction of approximately $15 \%$ in mortality, this decrease was not statistically significant $(\mathrm{p}=0.850)$.

As shown in Figure 2 according to the multivariate logistic regression analyses, when mortality was adjusted for sex, age and groups, we identified that the use of ACE inhibitors and beta-blockers reduced the risk of death by 4.4 and 4.9 times, respectively. On the other hand, the need for inotropes increased the risk of death by 4.9 times. Although we observed a statistically significant difference in the use of statin, clopidogrel and glycoprotein IIb/IIIa inhibitors between the before and after groups, the use of these drugs was not associated with changes in mortality.

\section{Discussion}

Our study aimed at assessing the impact of implementing a CICU on clinical outcomes of patients with a diagnosis of STEMI. In our analysis, we could observe that there was an increase in the prescription of medications with

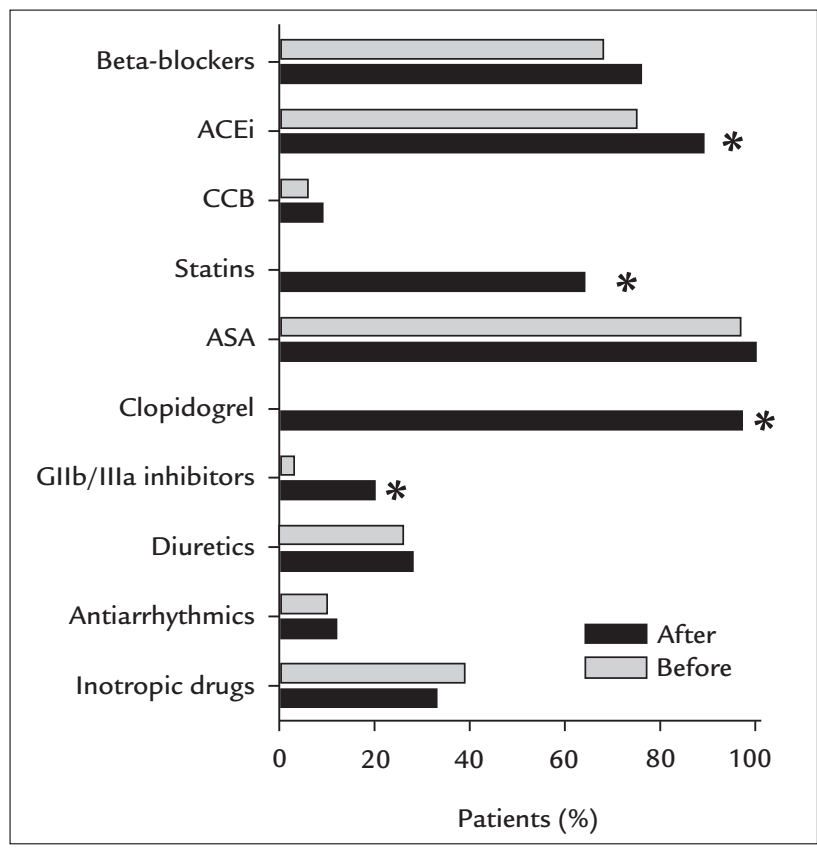

FIGURE 1 Treatment used in acute myocardial infarction during hospitalization. Group before: period prior to the creation of the intensive coronary unit (2000 to 2002); group after: period subsequent to the creation of the intensive coronary unit (2005 to 2006). ACEi: angiotensin II converting enzyme inhibitors; CCB: calcium channel blockers; ASA: acetylsalicylic acid; GIlb/IIla: glycoprotein IIb/IIla; * $<0.05\left(\chi^{2}\right)$. 


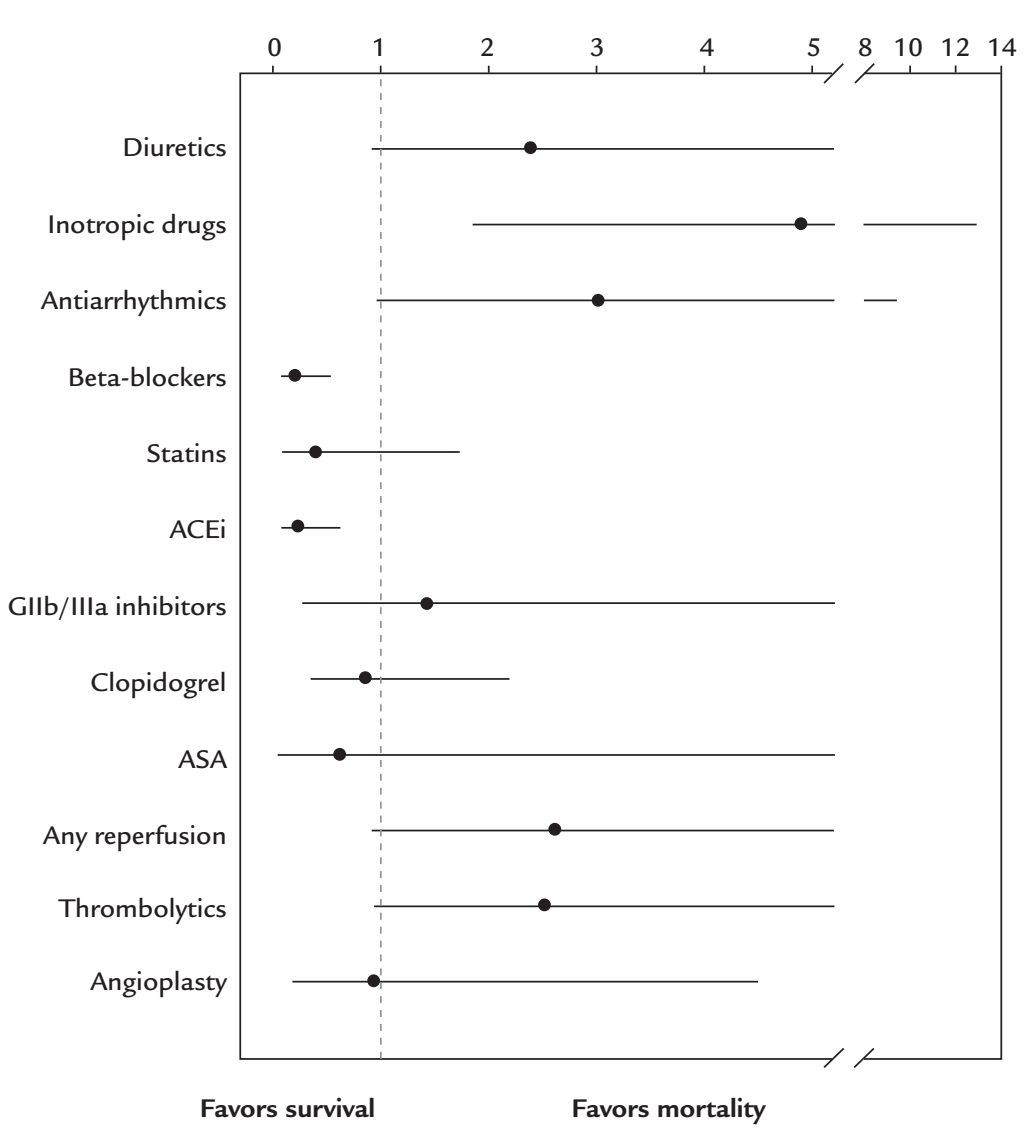

FIGURE 2 Multivariate logistic regression, showing the odds ratio for mortality among patients with acute ST segment elevation myocardial infarction. All analyses were adjusted for sex, age and group. The use of ACE inhibitors and beta-blockers reduced the risk of death by 4.4 and 4.9 times, respectively. Conversely, the need for inotropes increased the risk of death by 4.9 times. ASA: acetylsalicylic acid; ACEi: inhibitors of angiotensin II converting enzyme.

a recommendation for routine use in this clinical situation. However, these changes did not result in reduced mortality at 30 days.

Regarding the clinical characteristics of the patients, we could observe that our population had characteristics similar to those of other publications. ${ }^{20-23}$ Our patients were predominantly male, in the fifth and sixth decade of life, and had multiple risk factors. In agreement with literature data, we also observed a higher prevalence of anterior wall STEMI. ${ }^{14,24}$ This characteristic is associated with higher mortality, as it occurs more frequently with complications such as heart failure. ${ }^{2}$

The most important finding of our study was that the implementation of the CICU was not accompanied by a 30-day reduction in mortality. This finding, which at first may seem peculiar, can be explained in several ways.

We must take into account that mortality was low in both periods, which reduces the power of analysis to find potential differences. In addition, it is important to note that the mortality observed in both groups is close to the mortality of large clinical studies for the treatment of patients with infarction. ${ }^{21-23,25}$

Another important aspect that may explain the lack of impact after the implementation of the CICU refers to adherence to the treatment recommended by different guidelines in the two periods. Almost all patients were treated with ASA and most of the patients underwent reperfusion therapy. Thus, our data suggest that performing or not reperfusion may be more important than the reperfusion method itself. This can have important implications, since a significant portion of services in our country does not have primary angioplasty services. ${ }^{26}$ Also, we observed that, in multivariate logistic regression, the use of beta-blocker decreased the chance of death by 4.9 times. The same happens with the use of ACE inhibitors, so that patients treated with these drugs had a 4.4-fold reduction in 
the risk of death. The fact that we observed no difference in mortality between the before and after groups may be due to the large number of patients using these medications. Even in the period prior to the creation of CICU, nearly $70 \%$ and more than $75 \%$ of patients used beta-blockers and ACE inhibitors, respectively. Finally, surprisingly, we determined that the use of statins did not result in differences in short-term mortality, suggesting that this class of drugs may have more impact on the prognosis with chronic use.

The third factor to be considered in the analysis of our results is that, in our service, patients diagnosed with STEMI were treated in regular intensive care units (ICUs) prior to the implementation of CICU. It is already well-established that the main factor associated with the reduction of mortality with the implementation of CICUs is the monitoring of patients. It is known that 30 to $40 \%$ of patients with STEMI do not reach the hospital. Similarly, 50 to $65 \%$ of patients die in the first hour and up to $85 \%$ of deaths occur on the first day after the ischemic event. ${ }^{26}$ One of the main causes is the appearance of malignant arrhythmias, especially sustained ventricular tachycardia and ventricular fibrillation. ${ }^{26,27}$ Therefore, we believe that patient monitoring, performed in general ICUs, can have the same impact as the monitoring performed at specific sites for the treatment of acute coronary syndromes.

Although this was not the main focus of our study, a factor that draws attention is the time elapsed between onset of precordial pain and arrival at the emergency service. Approximately one quarter of the patients came to the service with a pain time greater than 12 hours, a period in which myocardial damage may be irreversible and myocardial preservation therapies are less effective. In this context, we must consider that our hospital is one of the reference tertiary hospitals in that specific region of the countryside of the state of São Paulo, which includes 68 municipalities, sometimes distant from each other, and this can delay patient referral. Additionally, educational measures for the population, informing people about the symptoms of acute coronary syndromes and the need to seek health care promptly, could contribute to reducing the time of arrival of these patients to the hospital. ${ }^{2}$

Our results should be analyzed considering some limitations. Our study was retrospective and included a relatively small number of patients. In addition, patients from only one center were analyzed. However, despite these limitations, we believe that our data allow the hypothesis that the physical environment has limited relevance in the care of patients with infarction. Thus, the most important thing in this scenario would be the cor- rect monitoring of patients and adherence to care recommended by guidelines for the treatment of STEMI.

\section{Conclusion}

Our study suggests that, in patients with STEMI, the implementation of a CICU was not associated with a 30-day reduction in mortality.

\section{ACKNOWLEDGMENTS}

We thank the National Council for Scientific and Technological Development (CNPq), for its scientific initiation grant.

\section{Conflict of interest}

The authors declare no conflict of interest.

\section{Resumo}

Impacto da unidade coronariana no tratamento do infarto do miocárdio

Introdução: Apesar da diminuição da mortalidade por infarto agudo do miocárdio com supradesnivelamento do segmento ST (IAM-ST) no mundo, a doença ainda acarreta elevados custos e morbidade. Muitas medidas contribuem para a redução da mortalidade, dentre elas a criação de unidades intensivas coronarianas (UCO).

Objetivo: Avaliar o impacto da criação de uma UCO na prescrição de tratamentos preconizados e na mortalidade em 30 dias em pacientes com IAM-ST.

Método: Foi realizado estudo retrospectivo e foram coletados dados de prontuários de pacientes internados na UCO de 2005 a 2006 (grupo depois). Esses dados foram comparados com dados do serviço de 2000 a 2002, previamente à criação da UCO (grupo antes).

Resultados: Havia 101 e 143 pacientes nos grupos depois e antes, respectivamente. Não houve diferenças em relação às características populacionais e às características do infarto entre os períodos. Observamos aumento na prescrição de iECA, clopidogrel e estatinas. Apesar da ausência de mudanças no número de pacientes que receberam terapia de reperfusão, houve aumento de angioplastias primárias em detrimento ao uso de trombolíticos no período posterior à criação da UCO. Não observamos diminuição da mortalidade em 30 dias após IAM-ST (antes: $10,5 \%$; depois: $8,9 \%$; $\mathrm{p}=0,850)$, mas a prescrição de tratamentos preconizados foi alta em ambos os períodos. O uso de iECA e de betabloqueador diminuiu o risco de morte em 4,4 e 4,9 vezes, respectivamente. 
Conclusão: Em pacientes com IAM-ST, a criação da UCO não reduziu a mortalidade em 30 dias, mas houve aumento na prescrição de tratamentos preconizados.

Palavras-chave: mortalidade, inibidores da enzima conversora de angiotensina, antagonistas adrenérgicos.

\section{References}

1. de Andrade L, Zanini V, Batilana AP, de Carvalho EC, Pietrobon R, Nihei $\mathrm{OK}$, et al. Regional disparities in mortality after ischemic heart disease in a Brazilian state from 2006 to 2010. PLoS One. 2013; 8:e59363.

2. Task Force on the management of ST-segment elevation acute myocardial infarction of the European Society of Cardiology (ESC), Steg PG, James SK, Atar D, Badano LP, Blomstrom-Lundqvist C, et al. ESC Guidelines for the management of acute myocardial infarction in patients presenting with ST segment elevation. Eur Heart J. 2012; 33(20):2569-619.

3. Fox KA, Dabbous OH, Goldberg RJ, Pieper KS, Eagle KA, Van de Werf F, et al. Prediction of risk of death and myocardial infarction in the six months after presentation with acute coronary syndrome: prospective multinational observational study (GRACE). BMJ. 2006; 333(7578):1091.

4. Canto AJ, Kiefe CI, Goldberg RJ, Rogers WJ, Peterson ED, Wenger NK, et al. Differences in symptom presentation and hospital mortality according to type of acute myocardial infarction. Am Heart J. 2012; 163(4):572-9.

5. Mandelzweig L, Battler A, Boyko V, Bueno H, Danchin N, Filippatos G, et al. The second Euro Heart Survey on acute coronary syndromes: characteristics, treatment, and outcome of patients with ACS in Europe and the Mediterranean Basin in 2004. Eur Heart J. 2006; 27(19):2285-93.

6. Jernberg T, Johanson P, Held C, Svennblad B, Lindbäck J, Wallentin L; SWEDEHEART/RIKS-HIA. Association between adoption of evidence-based treatment and survival for patients with ST-elevation myocardial infarction JAMA. 2011; 305(16):1677-84

7. McManus DD, Gore J, Yarzebski J, Spencer F, Lessard D, Goldberg RJ. Recent trends in the incidence, treatment, and outcomes of patients with STEMI and NSTEMI. Am J Med. 2011; 124(1):40-7.

8. Mansur AP, Favarato D, Avakian SD, Ramires JA. Trends in ischemic heart disease and stroke death ratios in Brazilian women and men. Clinics (Sao Paulo). 2010; 65(11):1143-7.

9. Mansur AP, Lopes AI, Favarato D, Avakian SD, César LA, Ramires JA. Epidemiologic transition in mortality rate from circulatory diseases in Brazil. Arq Bras Cardiol. 2009; 93(5):506-10.

10. Soares GP, Brum JD, Oliveira GM, Klein CH, Souza e Silva NA. Evolution of socioeconomic indicators and cardiovascular mortality in three Brazilian states. Arq Bras Cardiol. 2013; 100(2):147-56.

11. Baena CP, Chowdhury R, Schio NA, Sabbag AE Jr, Guarita-Souza LC, Olandoski $\mathrm{M}$, et al. Ischaemic heart disease deaths in Brazil: current trends, regional disparities and future projections. Heart. 2013; 99(18):1359-64

12. Zornoff LA, Paiva SA, Assalin VM, Pola PM, Becker LE, Okoshi MP, et al. Clinical profile, predictors of mortality, and treatment of patients after myocardial infarction, in an academic medical center hospital. Arq Bras Cardiol. 2002; 78(4):396-405.
13. Bordon JG, Paiva SA, Matsubara LS, Inoue RM, Matsui M, Gut AL, et al. Mortality decline after implementation of standard protocols for treating patients with acute myocardial infarction. Arq Bras Cardiol. 2004; 82(4):370-7.

14. Okura N, Ogawa H, Katoh J, Yamauchi T, Hagiwara N. Long-term prognosis of patients with acute myocardial infarction in the era of acute revascularization (from the Heart Institute of Japan Acute Myocardial Infarction [HIJAMI] registry). Int J Cardiol. 2012; 159(3):205-10.

15. Killip T 3rd, Kimball JT. Treatment of myocardial infarction in a coronary care unit. A two year experience with 250 patients. Am J Cardiol. 1967; 20(4):457-64.

16. Rotstein Z, Mandelzweig L, Lavi B, Eldar M, Gottlieb S, Hod H. Does the coronary care unit improve prognosis of patients with acute myocardial infarction? A thrombolytic era study. Eur Heart J. 1999; 20(11):813-8.

17. Karlson BW, Herlitz J, Wiklund O, Pettersson P, Hallgren P, Hjalmarson A. Characteristics and prognosis of patients with acute myocardial infarction in relation to whether they were treated in the coronary care unit or in another ward. Cardiology. 1992; 81(2-3):134-44.

18. Nasi LA, Ferreira-Da-Silva AL, Martins SC, Furtado MV, Almeida AG, Brondani R, et al. Implementation of a dedicated cardiovascular and stroke unit in a crowded emergency department of a tertiary public hospital in Brazil: effect on mortality rates. Acad Emerg Med. 2014; 21(1):40-6.

19. Loughran J, Puthawala T, Sutton BS, Brown LE, Pronovost PJ, DeFilippis AP. The cardiovascular intensive care unit-an evolving model for health care delivery. J Intensive Care Med. 2017; 32(2):116-23

20. Bacci MR, Fonseca FL, Nogueira LF, Bruniera FR, Ferreira FM, Barros DM, et al. Predominance of STEMI and severity of coronary artery disease in a cohort of patients hospitalized with acute coronary syndrome: a report from ABC Medical School. Rev Assoc Med Bras. 2015; 61(3):240-3.

21. Gottlieb S, Goldbourt U, Boyko V, Harpaz D, Mandelzweig L, Khoury Z, et al. Mortality trends in men and women with acute myocardial infarction in coronary care units in Israel. A comparison between 1981-1983 and 19921994. For the SPRINT and the Israeli Thrombolytic Survey Groups. Eur Heart J. 2000; 21(4):284-95.

22. Chung SC, Sundstrom J, Gale CP, James S, Deanfield J, Wallentin L, et al Comparison of hospital variation in acute myocardial infarction care and outcome between Sweden and United Kingdom: population based cohort study using nationwide clinical registries. BMJ. 2015; 351:h3913.

23. Chung SC, Gedeborg R, Nicholas O, James S, Jeppsson A, Wolfe C, et al. Acute myocardial infarction: a comparison of short-term survival in national outcome registries in Sweden and the UK. Lancet. 2014; 383(9925):1305-12.

24. El Khoury C, Bochaton T, Flocard E, Serre P, Tomasevic D, Mewton N, et al.; Observatoire des Syndromes Coronaires Aigus dans RESCUe (OSCAR) Research Team. Five-year evolution of reperfusion strategies and early mortality in patients with ST-segment elevation myocardial infarction in France. Eur Heart J Acute Cardiovasc Care. 2015; pii: 2048872615623065 [in press].

25. Ratcliffe JA, Wilson E, Islam S, Platsman Z, Leou K, Williams G, et al. Mortality in the coronary care unit. Coron Artery Dis. 2014; 25(1):60-5.

26. Piegas LS, Timerman A, Feitosa GS, Nicolau JC, Mattos LAP, Andrade MD et al. V Diretriz da Sociedade Brasileira de Cardiologia sobre tratamento do infarto agudo do miocárdio com supradesnível do segmento ST. Arq Bras Cardiol. 2015; 105(2):1-105

27. Orvin K, Eisen A, Goldenberg I, Gottlieb S, Kornowski R, Matetzky S, et al Outcome of contemporary acute coronary syndrome complicated by ventricular tachyarrhythmias. Europace. 2016; 18(2):219-26. 